\title{
CROP LOAD REGULATION WITH CHEMICAL THINNERS IN DEVECI PEAR (PYRUS COMMUNIS L.)
}

\author{
KAÇAL, E. \\ Department of Fruit Breeding and Genetic, Fruit Research Institute, 32500 Eğirdir, Isparta, Turkey \\ (e-mail: emel.vural@gmail.com; phone: +90-246-313-2420-112; fax: +90-246-313-2425) \\ (Received $3^{\text {rd }}$ Aug 2018; accepted $28^{\text {th }}$ Sep 2018)
}

\begin{abstract}
The efficacy of three different doses of ammonium thiosulfate (ATS), potassium thiosulfate (KTS) and BA (6-benzyladenine) on fruit quality, yield and return bloom was evaluated in this present experiment on 'Deveci' pear (Pyrus communis, L.). All treatments were compared to an unsprayed control and hand fruit thinning. The highest fruit set was achieved with BA treatments. It was significantly reduced in KTS rates compared to control and other thinning treatments. KTS sprays create a statistically significant increase in fruit diameter and fruit weight, while ATS and BA have had no dramatic effect. Hand fruit thinning has resulted in heavier fruit at harvest similar to KTS with $2 \%$. Thinners increased the percentage of fruit to $\geq 75 \mathrm{~mm}$ in diameter and proportions to $250-500 \mathrm{~g}$ fruit weight. In the control trees, the ratio of fruit to $\geq 75 \mathrm{~mm}$ diameter was $57 \%$, the $75 \%$ or more of which was in hand thinning and chemical thinners. The proportion of fruits within 250-500 g fruit weight group was found in the highest KTS doses. No physiological disorder as bitter pit, water core, and aging disorder and phytotoxicity were observed in fruit samples. Study results show that $2 \%$ KTS significantly reduce crop load and increased fruit quality in 'Deveci' pear. Therefore, it can be used as an alternative to hand fruit thinning in the 'Deveci' pear to achieve high fruit quality. But, neither flower nor fruit thinners induced return bloom in 'Deveci' pear.
\end{abstract}

Keywords: alternate bearing, 6-BA, blossom thinners, fruit quality, yield efficiency

\section{Introduction}

Turkey is among the top 10 pear producers in the world with 420.000 tons of pear production. Although pears are grown throughout the country, production is mainly focused around the Southern Marmara, Northern Mediterranean and Central Anatolia Regions. Many different varieties of pears are grown in Turkey. Most popular pear varieties are 'Santa Maria', 'Deveci', 'Akca', 'Mustafabey', 'Williams', 'Kieffer', and 'Ankara'. 'Deveci', which is an Anatolian origin, is one of the major pear varieties produced in Turkey. It constitutes $20 \%$ of production (Atalaysun, 2016) and is very popular among consumers because of having large fruit and high consumption quality. 'Deveci' is a variety with biennial bearing. If there is no thinning in the "on year", no flower may be in the next year. Alternate bearing or biennial bearing is common in temperate fruit trees such as apple, pistachio, pear and olive. Genetic predisposition has an important role in the occurrence of alternate bearing, but it is possible to reduce it with plant nutrition practices and crop load management. Crop load management is one of the most important horticultural practices for sustainable fruit quality and quantity (Yıldirım and Koyuncu, 2004). Thinning applications can be performed in different phenological periods such as buds, flowers and fruits by different methods. Flower thinning is practiced to maximize crop value and promote return bloom when compared to fruitlet thinning. Early thinning will conserve photosynthetic reserves by reducing competition between all organs throughout the tree. Flower thinning can be conducted mechanically or chemically. But in practice, the most common method is the use of chemical thinners. Chemical blossom thinners are caustic and reduce fruit set by 
damaging different parts of the flower and prevent fertilization (Fallahi and Willemsen, 2002). Several chemicals like ATS, KTS, armothin, etc. have been identified to reduce fruit set when applied at the flowering time. Chemical fruit thinning is achieved by plant growth regulators such as BA, NAA, NAD when the fruits reach a certain size. Hand fruit thinning, one of the applications in crop load management, is not economical for industrial countries since it increases labour costs and is a time-consuming practice (Bangerth and Quinlan, 2000). Therefore, the interest in chemical thinners has also increased steadily.

Apple is the main fruit species in which thinning studies are widely performed due to high expectation of fruit quality and the tendency to alternate bearing. Many apple varieties have been tested for their response to chemical thinners in different ecologies. However, limited studies are available in the literature on pear. Crop load studies with chemicals have been conducted on 'Nijisseiki', 'Hosui', 'Conference', 'Forelle', 'Bartlett', 'Williams', 'Abbate Fetel', 'Williams Bon Chretien' and 'Packams Triumph' pears (McArtney and Wells, 1995; Maas and van der Steeg, 2011; Kirstein, 2015; Greene, 2012; Theron, 2011; Bound, 2015). The effects of Ethephon, NAA, BA, ABA, Metamitron, and ATS have been investigated in these studies. In the present work, it was evaluated the efficacy of three rates of ATS, KTS, and BA on fruit quality, crop load and return bloom in 'Deveci' pear grown on the Quince A rootstock.

\section{Materials and methods}

\section{Study area and plant material}

This study was conducted on the Fruit Research Institute (37\%49'1"9N, 30'52'23'E), Eğirdir, Isparta, Turkey in 2017-2018 vegetation periods. Isparta has favourable conditions for temperate fruit growing. It is very important apple production region within Turkey; it leading producer with about $25 \%$ of total. The Institute is located between Eğirdir and Kovada Lakes. The location is the transitional zone between the Mediterranean and the continental climate. The study area is $917 \mathrm{~m}$ above sea level. The average temperature is $12.2^{\circ} \mathrm{C}$ and the annual rainfall is $564.3 \mathrm{~mm}(1929-2017)$. Some of the meteorological data recorded in the study area $\left(37^{\circ} 48^{\prime} 52^{\prime \prime} \mathrm{N}, 30^{\circ} 52^{\prime} 30^{\prime \prime} \mathrm{E}\right)$ are presented in Table 1.

Table 1. The recorded monthly meteorological data of the experimental area (2017 year)

\begin{tabular}{c|c|c|c|c|c|c|c|c|c|c|c|c}
\hline & Jan. & Feb. & Mar. & Apr. & May & June & July & Aug. & Sept. & Oct. & Nov. & Dec. \\
\hline Avg. temp. $\left({ }^{\circ} \mathrm{C}\right)$ & 0.57 & 1.52 & 7.6 & 10.9 & 15.21 & 19.28 & 23.38 & 22.78 & 19.57 & 12.23 & 6.91 & 5.37 \\
Min. temp. $\left({ }^{\circ} \mathrm{C}\right)$ & -4.38 & 0.87 & 1.05 & 3.97 & 8.43 & 11.73 & 14.65 & 14.77 & 9.53 & 5.19 & 0.75 & 1.06 \\
Max. temp. $\left({ }^{\circ} \mathrm{C}\right)$ & 5.51 & 2.16 & 14.15 & 17.83 & 22 & 26.83 & 32.11 & 30.78 & 29.61 & 19.27 & 13.06 & 9.68 \\
Avg. hum. $(\%)$ & 76.24 & 70.8 & 65.89 & 61.61 & 67.91 & 66.75 & 49.27 & 61.38 & 56.49 & 69.99 & 82.8 & 85.96 \\
Total rainfall (mm) & 188.6 & 0.65 & 88 & 84.2 & 73 & 60.8 & 0.4 & 24.6 & 0.8 & 82.8 & 81 & 181.6 \\
\hline
\end{tabular}

'Deveci' pear tree, 16-year-old, at a spacing of $4.0 \times 2 \mathrm{~m}$ in north-south rows on Quince A rootstock, was selected as experimental trees. 'Deveci' trees grow semivigour and are semi-spreading. The number of days between full bloom and harvest is 150-160. Ripening season is around 15-20 October. Eleven applications including 
unsprayed control (no thinning), hand fruit thinning (HFT) just after June drops (one fruitlet left per cluster), ammonium thiosulfate (ATS) $(1.0 \%, 2.0 \%, 3.0 \%)$, potassium thiosulfate (KTS) and BA (6-benziyladenine) (Exilis $\left.{ }^{\circledR}\right)\left(100,125\right.$ and $150 \mathrm{mg} \mathrm{l}^{-1}$ ) were designed. The applications were performed by spraying on the predetermined healthy trees by handgun sprayer. All sprays were applied to the whole tree and no surfactant was used. Detailed information about experiments is given in Table 2.

Table 2. Thinning practices, application time and date

\begin{tabular}{c|c|c|c}
\hline Treatments & Doses & Application period & Application date \\
\hline Control & - & - & - \\
\hline HFT & - & After June drop (one fruit was left in each flower cluster) & 06.06 .2017 \\
\hline \multirow{3}{*}{ ATS } & $1 \%$ & & \\
& $2 \%$ & & \\
& $3 \%$ & Full bloom (70-80\%) & 19.04 .2017 \\
KTS & $1 \%$ & & \\
& $2 \%$ & & \\
& $3 \%$ & $10-12 \mathrm{~mm}$ fruit diameter & 12.05 .2017 \\
\hline \multirow{3}{*}{ BA } & $100 \mathrm{mg} \mathrm{l}^{-1}$ & & \\
& $125 \mathrm{mg} \mathrm{l}^{-1}$ & & \\
\hline
\end{tabular}

The experimental area was irrigated twice a week by drip irrigation and the fertilizers were given based on the soil analysis results. The soil of the experimental area was loamy-clay. It contains $2.8 \%$ organic matter. During the trial, orchard management practices were carried routinely and spray program was followed for plant health.

\section{Measurements}

Fruits were harvested at commercial harvest time in 16.10.2017. Ten fruits were selected randomly per tree for fruit quality measurements such as fruit length $(\mathrm{mm})$, fruit diameter $(\mathrm{mm})$, fruit weight $(\mathrm{g})$, fruit flesh firmness $(\mathrm{N})$, soluble solid contents (SSC) and titratable acidity (TA). A total of 120 fruits were analysed in each application. Fruit samples were also assessed for physiological disorders. They were graded into various sizes and weight classes. Different groups were formed between $100-500 \mathrm{~g}$ for fruit weight and $65-90 \mathrm{~mm}$ for fruit diameter.

All flower clusters were counted to determine fruit set ratio at pink bloom stage and the number of fruits per tree. The yield was recorded in each tree at harvest. During the winter period, the stem diameter was measured at a height of $15 \mathrm{~cm}$ from the graft union and the trunk cross-sectional area (TCSA) as calculated $\left(\pi r^{2}\right)$.

A few days after application, macroscopic observations were made for phytotoxic effects of thinners on tree organs. This trial was planned for two vegetation years and no thinning applications could be made because of alternate bearing in 2018. Thus, flowers were only counted for return bloom in 2018. During the spraying period, meteorological data were taken in order to determine the effects of temperature and relative humidity on thinning mode of chemicals (Fig. 1). 

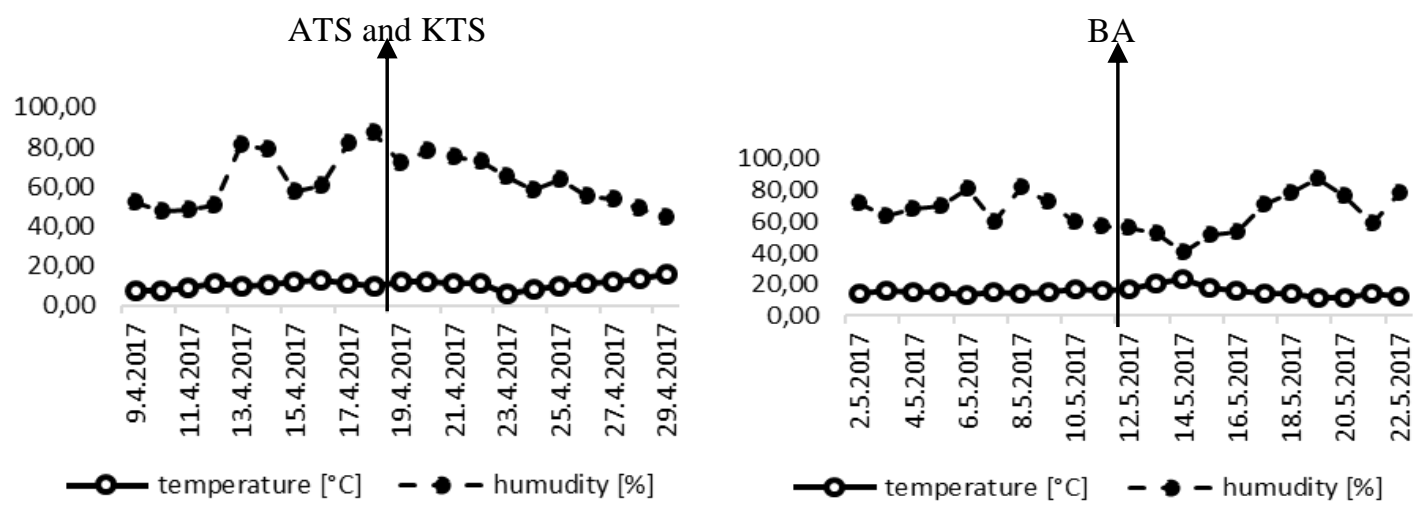

Figure 1. Temperature and relative humidity in the application period

\section{Statistical analysis}

Experiments were arranged in a randomized complete block design with four replicates, three trees were used for each replicate. Statistical procedures were performed using statistical analysis systems SPSS software. Duncan's multiple range test was used for means separation at a significance level of 5\%.

\section{Results and discussion}

\section{Fruit set and cropping}

In this study, fruit set was affected by treatments. Differences among treatments on fruit set and cropping were significantly at 5\% level. It is tended to decline with increased rates of KTS. ATS at 3\% and KTS at 3\% spraying significantly reduced fruit set, whereas BA did not. This data is not overlapping with findings of Chabikwa (2008), Bound and Mitchell (2002), Curetti et al. (2011) and Bertelsen (2002) on 'Early Bon Chretien', 'Packam's Triumph', 'Williams' and 'Clara Frijs' pears for BA. But these results are similar to Greene (2012) who works on 'Bartlett' pear. Low temperatures at application time could reduce BA efficiency. The highest ATS rate caused approximately $42.86 \%$ reduction in fruit set in comparison with untreated control. That was $52.29 \%$ compared to $125 \mathrm{mg} \mathrm{l}^{-1}$ BA. In BA and ATS, yield was higher than KTS doses and the highest yield was obtained from ATS as $2 \%$. ATS and KTS reduced yield at harvest as $3 \%$ and $1 \%$ respectively. But, the lowest fruit yield with the $30.89 \mathrm{~kg}^{-1}$ was taken from hand fruit thinning trees. $100 \mathrm{mg}^{-1} \mathrm{BA}$ was the best practice for yield efficiency compared to untreated control and others (Table 3).

\section{Fruit quality}

Significant differences were found among treatments on fruit quality parameters in comparison with the unsprayed control. All thinning practices increase fruit quality statistically $(P \leq 0.05)$ at varying rates compared to control. KTS sprays increased fruit diameter and fruit weight, while ATS and BA had no significant effect. Hand fruit thinning has resulted in heavier fruit at harvest similar to KTS as $2 \%$ (Table 4). ATS doses used in this study, being a promising thinner for 'Packham's Triumph' (Bound, 2015) and 'Clara Frijs' (Bertelsen, 2002) pears, were not as effective as hand fruit thinning and KTS doses on the fruit quality. 
Table 3. Effect of thinners on fruit set and cropping

\begin{tabular}{c|c|c|c|c}
\hline Treatments & Doses & $\begin{array}{c}\text { Fruit set (fruitlets/100 } \\
\text { flower clusters) }\end{array}$ & $\begin{array}{c}\text { Yield } \\
\left(\mathbf{k g ~ t r e e}^{-1}\right)\end{array}$ & $\begin{array}{c}\text { Yield efficiency } \\
\left(\mathbf{k g ~ c m}^{-2}\right)\end{array}$ \\
\hline Control & - & $11.85 \mathrm{abc}^{*}$ & $38.83 \mathrm{abc}$ & $0.17 \mathrm{ab}$ \\
\hline HFT & - & $9.20 \mathrm{abc}$ & $30.89 \mathrm{c}$ & $0.14 \mathrm{ab}$ \\
\hline \multirow{3}{*}{ ATS } & $1 \%$ & $10.99 \mathrm{abc}$ & $42.80 \mathrm{abc}$ & $0.17 \mathrm{ab}$ \\
& $2 \%$ & $11.69 \mathrm{abc}$ & $47.19 \mathrm{a}$ & $0.12 \mathrm{~b}$ \\
& $3 \%$ & $6.77 \mathrm{c}$ & $31.68 \mathrm{bc}$ & $0.13 \mathrm{~b}$ \\
\hline \multirow{3}{*}{ KTS } & $1 \%$ & $10.05 \mathrm{abc}$ & $31.39 \mathrm{c}$ & $0.13 \mathrm{~b}$ \\
& $2 \%$ & $9.73 \mathrm{abc}$ & $38.15 \mathrm{abc}$ & $0.15 \mathrm{ab}$ \\
& $3 \%$ & $8.56 \mathrm{bc}$ & $36.15 \mathrm{abc}$ & $0.16 \mathrm{ab}$ \\
\hline \multirow{3}{*}{$\mathrm{BA}$} & $100 \mathrm{mg} \mathrm{l}^{-1}$ & $12.59 \mathrm{ab}$ & $41.76 \mathrm{abc}$ & $0.19 \mathrm{a}$ \\
& $125 \mathrm{mg} \mathrm{l}^{-1}$ & $14.19 \mathrm{a}$ & $44.41 \mathrm{ab}$ & $0.17 \mathrm{ab}$ \\
& $150 \mathrm{mg} \mathrm{l}^{-1}$ & $11.29 \mathrm{abc}$ & $34.28 \mathrm{bc}$ & $0.15 \mathrm{ab}$ \\
\hline
\end{tabular}

*Means in columns followed by the same letters are not significantly different at $5 \%$ level

Table 4. Effects of treatments on some fruit quality parameters

\begin{tabular}{c|c|c|c|c|c}
\hline Treatments & Doses & $\begin{array}{c}\text { Fruit width } \\
(\mathbf{m m})\end{array}$ & $\begin{array}{c}\text { Fruit weight } \\
(\mathbf{g})\end{array}$ & Shape index & $\begin{array}{c}\text { Fruit flesh } \\
\text { firmness (N) }\end{array}$ \\
\hline Control & - & $76.57 \mathrm{~d}^{*}$ & $222.58 \mathrm{e}$ & $0.90 \mathrm{abc}$ & $43.73 \mathrm{f}$ \\
\hline HFT & - & $80.85 \mathrm{ab}$ & $263.60 \mathrm{a}$ & $0.89 \mathrm{bc}$ & $43.96 \mathrm{f}$ \\
\hline \multirow{3}{*}{ ATS } & $1 \%$ & $78.50 \mathrm{c}$ & $237.04 \mathrm{de}$ & $0.89 \mathrm{bc}$ & $45.84 \mathrm{cde}$ \\
& $2 \%$ & $78.36 \mathrm{~cd}$ & $239.68 \mathrm{bcde}$ & $0.90 \mathrm{abc}$ & $49.80 \mathrm{a}$ \\
& $3 \%$ & $80.09 \mathrm{abc}$ & $257.39 \mathrm{abc}$ & $0.89 \mathrm{bc}$ & $47.91 \mathrm{~b}$ \\
\hline \multirow{3}{*}{ KTS } & $1 \%$ & $80.29 \mathrm{abc}$ & $258.61 \mathrm{ab}$ & $0.91 \mathrm{ab}$ & $46.84 \mathrm{bcd}$ \\
& $2 \%$ & $81.67 \mathrm{a}$ & $267.13 \mathrm{a}$ & $0.88 \mathrm{c}$ & $46.37 \mathrm{bcd}$ \\
& $3 \%$ & $79.65 \mathrm{abc}$ & $251.21 \mathrm{abcd}$ & $0.89 \mathrm{bc}$ & $47.44 \mathrm{bc}$ \\
\hline \multirow{3}{*}{ BA } & $100 \mathrm{mg} \mathrm{l}^{-1}$ & $79.49 \mathrm{bc}$ & $249.09 \mathrm{abcd}$ & $0.92 \mathrm{a}$ & $45.20 \mathrm{def}$ \\
& $125 \mathrm{mg} \mathrm{l}^{-1}$ & $79.47 \mathrm{bc}$ & $241.42 \mathrm{bcde}$ & $0.89 \mathrm{bc}$ & $46.29 \mathrm{bcd}$ \\
& $150 \mathrm{mg} \mathrm{l}^{-1}$ & $78.59 \mathrm{c}$ & $237.94 \mathrm{cde}$ & $0.89 \mathrm{bc}$ & $44.57 \mathrm{ef}$ \\
\hline
\end{tabular}

*Means in columns followed by the same letters are not significantly different at $5 \%$ level

ATS increased fruit diameter and fruit weight $3 \%$ relative to other ATS rates. Multiple applications of the ATS may also have a better thinning effect on the 'Deveci' variety, such as 'Packham's Triumph' (Bound and Mitchell, 2002). Compared to ATS and unsprayed control, KTS doses gave good results on fruit quality. However, the $2 \%$ KTS was more effective than the $1 \%$ KTS and 3\% KTS. BA applications were made when the fruit diameter was 8-12 mm. Although the doses of 50-200 $\mathrm{mg}^{-1}$ have been used in practice, the thinning effect of $100-150 \mathrm{mg} \mathrm{l}^{-1} \mathrm{BA}$ has been found promising for some varieties. Theron et al. (2011) reported that the application of 100-150 mg $\mathrm{l}^{-1} \mathrm{BA}$ on 8-12 mm fruit diameter in 'Early Bon Chretien' pear greatly reduced fruit set and that the thinning effect of $150 \mathrm{mg} \mathrm{l}^{-1} \mathrm{BA}$ was higher. In the literature, although the positive effects of BA on fruit thinning in pear are mentioned, it is reported that some pear varieties do not respond to fruit thinning applications. Reactions of varieties to 
chemical thinners may differ. Greene (2012) informed that BA was not effective in 'Bartlett's' pear, while Maas and Van der Steeg (2011) in 'Conference', Bound (2015), in 'Packham's Triumph' and Bertelsen (2002) in 'Clara Frijs' pear could be recommended for thinning. In 'Forelle' pear variety, BA + NAA applications reduced fruit set more than single applications of BA (Kirstein, 2015). In our study, although BA treatments increased fruit quality compared to control, they did not exceed KTS, ATS and hand fruit thinning with regards to efficacy. It is thought that this situation may be related to the climatic conditions at the time of application with the variety response. This is because the air temperature in the application period was around $15{ }^{\circ} \mathrm{C}$, which is the limit value for BA. Low temperatures during the application period may have overshadowed the effectiveness of the BA. In contrast, Bregoli et al. (2006) stated that the effect of BA may be related to the king fruit size rather than climatic conditions. In this study, BA treatments were made 24 days after full bloom when the fruit diameter reached $10-12 \mathrm{~mm}$. It is also possible that the phenological period at the time of application may not be suitable for BA in Deveci, or BA alone may be inadequate for a good thinning effect. As a matter of fact, Kurnaz et al. (1992) suggested that NAA and Carbaryl applications in 'Deveci' pear are not enough alone to be as effective as hand fruit thinning on fruit weight and size.

The fruit flesh firmness in ATS reached the highest value of $2 \%$, but it was significantly $(\mathrm{P} \leq 0.05)$ reduced in control and hand fruit thinning fruits. It is thought that the fruits of this application have more cells, but these cells do not reach sufficient size because of high crop load. The positive effect of ATS on fruit flesh firmness has also been reported in previous studies in apples (Bound and Wilson, 2007). SSC values obtained in the current study were classified according to the applications. As a result of a yield decrease, SSC was higher in 3\% ATS and hand fruit thinning. Reductions in SSC with high crop load may have been the result of reductions in soluble carbohydrates, increased competition for assimilate between plant organs resulting from increased crop load. Similar findings were reported by Coneva and Cline (2006) in 'Redhaven' peaches. SSC is increasing due to the increase of ATS doses. Titratable acidity was unaffected by thinning (Table 5).

Table 5. Effects of treatments on soluble solids content and titratable acidity

\begin{tabular}{c|c|c|c}
\hline Treatments & Doses & SSC & TA \% \\
\hline Control & - & $12.4 \mathrm{bc}^{*}$ & $0.2^{\text {ns }}$ \\
\hline HFT & - & $13.6 \mathrm{a}$ & 0.3 \\
\hline \multirow{3}{*}{ ATS } & $1 \%$ & $12.5 \mathrm{bc}$ & 0.3 \\
& $2 \%$ & $12.8 \mathrm{abc}$ & 0.3 \\
& $3 \%$ & $13.7 \mathrm{a}$ & 0.3 \\
\hline \multirow{2}{*}{ KTS } & $1 \%$ & $13.1 \mathrm{abc}$ & 0.3 \\
& $2 \%$ & $12.5 \mathrm{bc}$ & 0.2 \\
& $3 \%$ & $13.2 \mathrm{abc}$ & 0.2 \\
\hline \multirow{3}{*}{ BA } & $100 \mathrm{mg} \mathrm{l}^{-1}$ & $13.3 \mathrm{abc}$ & 0.3 \\
& $125 \mathrm{mg} \mathrm{l}^{-1}$ & $12.3 \mathrm{c}$ & 0.3 \\
& $150 \mathrm{mg} \mathrm{l}^{-1}$ & $13.5 \mathrm{ab}$ & 0.2 \\
\hline
\end{tabular}

*Means in columns followed by the same letters are not significantly different at $5 \%$ level ns: not significant 
Fruit size in 'Deveci' pear is an important trait, and it is linked to eating quality. Fruit juiciness and crispness reduce when fruit size decreases. It was determined that in control trees where no application was made, the fruit diameter and weight, as well as the fruit flesh firmness, decreased (Table 4). The eating quality of these fruits is also lower relative to large fruits. The effect of thinners on fruit diameter distribution was different. The chemical thinners increased the percentage of fruit to $\geq 75 \mathrm{~mm}$ in diameter. In control trees, the ratio of fruit to $\geq 75 \mathrm{~mm}$ was $57 \%$, where ATS $2 \%$ and KTS $3 \%$ were $69 \%$. In KTS $2 \%, 80 \%$ of the fruits have $\geq 75 \mathrm{~mm}$. Fruit rate of to $\geq 85 \mathrm{~mm}$ was found to be higher in hand fruit thinning and KTS at 2\% (Fig. 2). The effect of KTS sprays on fruit size was the greatest.

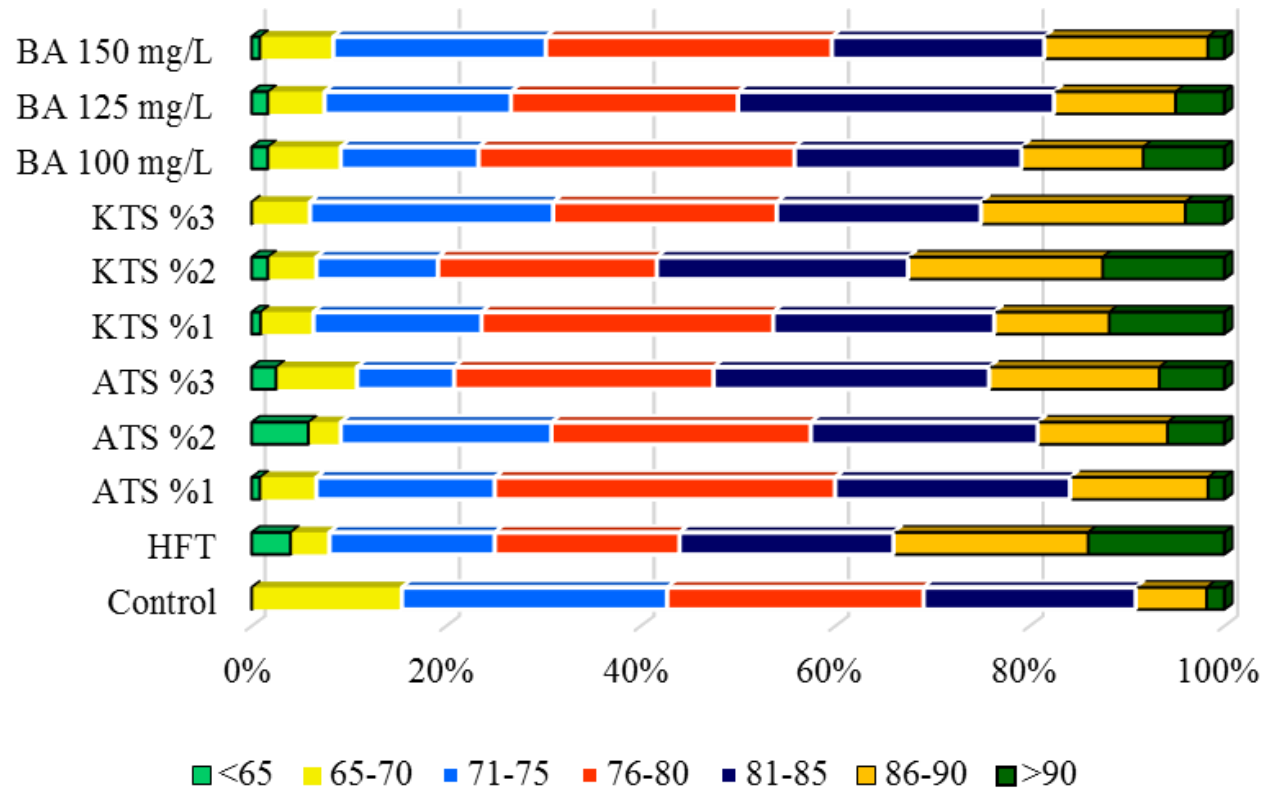

Figure 2. Effects of thinners on fruit size distribution ( $\mathrm{mm}$ )

'Deveci' pear can produce fruit up to $1500 \mathrm{~g}$ depending on the nutrition conditions and crop load. Although fruit size is an important factor for 'Deveci', over a certain size, it is not preferred by consumers. Ideal fruit weight for 'Deveci' is approximately between 250 and $450 \mathrm{~g}$. The fruits above $450 \mathrm{~g}$ are not demanded. The fruit weight of $250 \mathrm{~g}$ and above in KTS was higher than the other. Among the KTS doses, 2\% KTS was the most effective with 59.2\%. Hand fruit thinning was followed with 57\% to KTS. The lowest fruit rate was found in control with $32.7 \%$, while doses of ATS $1 \%$ and BA $150 \mathrm{mg} \mathrm{l}^{-1}$ were beyond all applications, except control trees. In BA applications, 50\% of the fruits reached to 100-250 g fruit weights (Table 6). The reduction of fruit size in 'Deveci' following application of BA contradicts the findings of Curetti et al. (2011) for 'Williams'.

\section{Return bloom}

Early thinning before seed development could increase return bloom. Also, crop load significantly affects it (Melan and Gjerde, 1993). This is particularly important for varieties showing alternate bearing. However, thinners positively affected the fruit quality in 'Deveci', they reduced return bloom dramatically in the second year of the 
experiment. Similar findings were found by Bound and Mitchell (2002) in 'Packham's Triumph' pear with ATS at 2\%. According to Forshey (1986), varieties showing alternate bearing generally do not respond to chemical thinners. In 2017, the highest number of flowers was recorded in the KTS 3\%. This was followed by ATS $2 \%$ and ATS 3\%. The number of flowers in the hand fruit thinning and BA $100 \mathrm{mg} \mathrm{l}^{-1}$ was lower, but the highest flower number was obtained from these applications in 2018 (Fig. 3). However, the efficiency of BA on return bloom was not at optimum level. This response is likely to be related to dose, application time, varietal characteristics or weather conditions. Additionally, spur leaf damage might be prevented to the formation of flower buds (Luckwill, 1970).

Table 6. Effects of thinners on fruit weight distribution $(g)$

\begin{tabular}{c|c|c|c|c|c|c|c|c}
\hline & $\mathbf{1 0 0 - 1 5 0}$ & $\mathbf{1 5 0 - 2 0 0}$ & $\mathbf{2 0 0 - 2 5 0}$ & $\mathbf{2 5 0 - 3 0 0}$ & $\mathbf{3 0 0 - 3 5 0}$ & $\mathbf{3 5 0 - 4 0 0}$ & $\mathbf{4 0 0 - 4 5 0}$ & $\mathbf{4 5 0 - 5 0 0}$ \\
\hline Control & 8.2 & 33.6 & 25.5 & 25.5 & 3.6 & 1.8 & 1.8 & 0.0 \\
HFT & 5.0 & 21.0 & 17.0 & 28.0 & 16.0 & 7.0 & 4.0 & 2.0 \\
ATS 1\% & 1.7 & 25.0 & 38.3 & 19.2 & 12.5 & 2.5 & 0.8 & 0.0 \\
ATS 2\% & 7.5 & 23.3 & 25.0 & 26.7 & 11.7 & 2.5 & 2.5 & 0.8 \\
ATS 3\% & 6.7 & 16.7 & 22.5 & 29.2 & 15.0 & 5.8 & 2.5 & 1.7 \\
KTS 1\% & 1.8 & 19.1 & 31.8 & 23.6 & 10.9 & 7.3 & 3.6 & 1.8 \\
KTS 2\% & 3.3 & 16.7 & 20.8 & 27.5 & 20.0 & 8.3 & 3.3 & 0.0 \\
KTS 3\% $_{\text {BA 100 mg l-1 }}^{-1}$ & 3.0 & 26.0 & 25.0 & 22.0 & 16.0 & 5.0 & 1.0 & 2.0 \\
BA 125 mg l & 2.5 & 15.8 & 40.0 & 23.3 & 13.3 & 4.2 & 0.8 & 0.0 \\
BA 150 mg l-1 & 5.0 & 22.5 & 30.8 & 23.3 & 15.0 & 3.3 & 0.0 & 0.0 \\
\hline
\end{tabular}

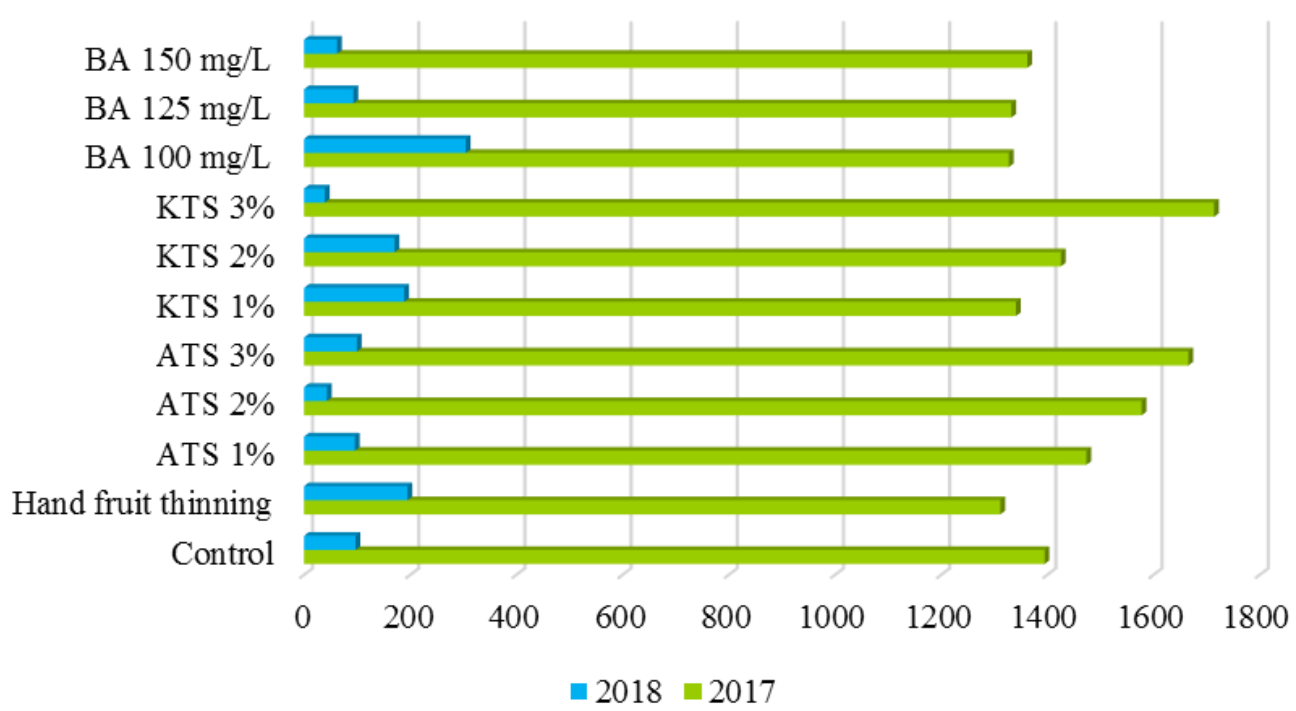

Figure 3. Effects of thinners on flower number in 2017 and 2018 years

\section{Phytotoxicity and physiological disorders}

Blossom thinners as ATS and KTS are caustic and they can cause damage on the development of spur leaves or other parts of the tree (Webster, 2002; Grenee, 2002). 
Factors such as weather conditions, high concentrations and variety characteristics often affect the thinners' response and damage ratio on the flower, spur leaves, young branches and fruits (Forshey, 1986; Kaçal and Koyuncu, 2012). Previous studies reported that high doses of ATS result in serious damage (Sanders and Looney, 1993; Janoudi and Flore, 2005). Phytotoxic effect of ATS than high doses, the previous day from the time of application occurred in cool, humid, and rainy weather (Schupp and Greene (2002). However, Bound and Jones (2004) performed that rates of 3\% ATS or higher doses caused foliar damage and bud death. KTS and ATS doses showed symptoms of leaf burning and chlorosis on spur leave a few days after application in this study resulting from low temperate and high humidity, but they did not affect fruit size. This damage has increased with increasing doses. No phytotoxicity was found in BA applications.

BA can cause russet on the fruit skin. This condition was observed by Greene (2002) on Bartlett pear. But in the case of excessive thinning, physiological disorders such as bitter pit and water core in fruits are likely to occur when the increase in fruit size and nutritional conditions are taken into account. However, during the experiment, no physiological disorder as bitter pit, water core, and aging disorder and phytotoxicity were observed.

\section{Conclusion}

Efficacy of ATS, KTS, and BA on the fruit quality and return bloom in 'Deveci' pear was evaluated in this experiment. Flower thinners reduce fruit set and yield and increase fruit quality. But neither flower nor fruit thinners induced return bloom. There is no record about what is the optimum fruit number for next year cropping and high fruit quality in 'Deveci'. Further detailed crop load studies should be done on 'Deveci' pear. Dose, application times, chemicals and combined use of either flower or fruit thinners, single applications or the sequential use of ATS and KTS should further be tested to create a thinning schedule for pear growers.

\section{REFERENCES}

[1] Atalaysun, M. (2016): Turkey fresh deciduous fruits report. - Gain Report TR6051.

[2] Bangerth, F., Quinlan, J. (2000): Editorial preface. - Plant Growth Regulation 31(1-2): $\mathrm{v}-\mathrm{vi}$.

[3] Bertelsen, M. G. (2002): Benzyladenine and other thinning agents for pear cv. 'Clara Frijs'. - J. Amer. Pomol. Soc. 56: 149-155.

[4] Bound, S. A. (2015): Optimizing crop load and fruit quality of 'Packham's Triumph' pear with ammonium thiosulfate, ethephon and 6-benzyladenine. - Scientia Hort. 192: 187196.

[5] Bound, S. A., Jones, K. M. (2004): Ammonium thiosulphate as a blossom thinner of 'Delicious' apple, 'Winter Cole' pear and 'Hunter' apricot. - Australian Journal of Experimental Agriculture 44: 931-937.

[6] Bound, S. A., Mitchell, L. (2002): The effect of blossom desiccants on crop load of Packham's Triumph pear. - Acta Horticulturae 596: 729-733.

[7] Bound, S. A., Wilson, S. J. (2007): Ammonium thiosulfate and 6-benzyladenine improve the crop load and fruit quality of 'Delicious' apples. - Australian Journal of Experimental Agriculture 47: 635-644. 
[8] Bregoli, A. M., Fabbroni, C., Vancini, R., Galliano, A., Costa, G. (2006): Results obtained on the efficacy of 6-BA alone, and in combination with other thinning agents from different apple producing areas of northern Italy Anna Maria. - Journal of Fruit and Ornamental Plant Research 14: 23-38.

[9] Chabikwa, T. G. (2008): Chemical thinning of European pear cultivars (Pyrus communis, L.). - Master of Science Dissertation, Stellenbosch University, South Africa.

[10] Coneva, E. D., Cline, A. (2006): Blossom thinners reduce crop load and increase fruit size and quality of peaches. - HortScience 41: 1253-1258.

[11] Curetti, M., Rodríguez, R., Magdalena, C., Rodríguez, A. (2011): Effect of concentration, application volume and addition of a surfactant on response to benzyladenine as thinning agent in 'Williams' pears. - Acta Horticulturae 909: 395-40.

[12] Fallahi, E., Willemsen, K. M. (2002): Blossom thinning of pome and stone fruit. Hortscience 7: 474-477.

[13] Forshey, C. G. (1986): Chemical fruit thinning of apples. - New York's Food and Life Sciences Bulletin, Number 116. New York State Agricultural Experiment Station, Geneva, a Division of the New York State College of Agriculture and Life Sciences, Cornell University, Ithaca.

[14] Greene, D. W. (2002): Chemicals, timing and environmental factors involved in thinner efficacy on apple. - HortScience 37: 477-481.

[15] Greene, D. W. (2012): Influence of abscisic acid and benzyladenine on fruit set and fruit quality of 'Bartlett' pears. - HortScience 47: 1607-1611.

[16] Janoudi, A., Flore, J. A. (2005): Application of ammonium thiosulfate for blossom thinning in apples. - Scientia Horticulturae 104: 161-168.

[17] Kaçal, E., Koyuncu, F. (2012): Use of chemical blossom thinners in 'Jerseymac' and 'Jonagold' apples. - Bulgarian Journal of Agricultural Science 18: 898-904.

[18] Kirstein, D. L. (2015): Mechanical thinning of Pome Fruit. - Doctoral Dissertation, Stellenbosch University, South Africa.

[19] Kurnaz, Ş., Özcan, M., Kopuzoğlu, N., Demirsoy, H. (1992): Effects of NAA, Carbaryl and hand thinning application on Deveci pear cultivar grown in Samsun. - Bahçe 21: 3-8.

[20] Luckwill, L. C. (1970): The Control of Growth and Fruitfulness of Apple Trees. - In: Luckwill, L. C., Cutting, C. V. (eds.) Physiology of Tree Crops. Academic Press, London.

[21] Maas, F. M., Van der Steeg, P. A. H. (2011): Crop load regulation in 'Conference' pears. - Acta Horticulturae 909: 369-380.

[22] McArtney, S. J., Wells, G. H. (1995): Chemical thinning of Asian and European pear with ethephon and NAA. - New Zealand Journal of Crop and Horticultural Science 23: 73-84.

[23] Meland, M., Gjerde, B. (1993): The effect of hand thinning on return bloom of Summerred and Aroma apples. - Acta Horticulturae 349: 219-222.

[24] Sanders, M., Looney, N. E. (1993): Ammonium thiosulphate (ATS) - a fertilizer that thins. - Tree Fruit Leader 2(1): 1-3.

[25] Schupp, J. R., Greene, D. W. (2002): Thinning McIntosh apple trees with blossom thinners, with and without post-bloom NAA: A report to the New England Tree Fruit Growers Research Committee. - Fruit Notes 67: 9-12.

[26] Theron, K. I., Chakbiwa, T. G., Lötze, G. F. A. (2011): Evaluation of 6-Benzyladenine (BA) and Naphthylacetamide (NAD) as post-bloom thinning compounds for 'Early Bon Chrétien' pear. - Acta Horticulturae 909: 387-394.

[27] Webster, T. (2002): Current approved thinning strategies for apples and pears and recent thinning research trials in Europe. - The Compact Fruit Tree 35: 73-76.

[28] Yıldırım, F., Koyuncu, F. (2004): Development of chemical thinning in apples. - Derim 21: 44-53. http://www.dergipark.gov.tr/download/article-file/52912. 